TAPROBANICA, ISSN 1800-427X. October, 2012. Vol. 04, No. 02: pp. 118-119, 2 pls.

(C) Taprobanica Private Limited, 146, Kendalanda, Homagama, Sri Lanka.

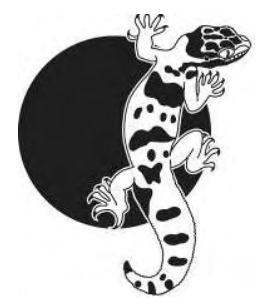

\section{A taxonomic note on Impatiens disotis Hooker, 1906 (Family: Balsaminaceae)}

The genus Impatiens consists of over 1000 species distributed in the Old World tropics and subtropics (Janssens et al., 2009, Yuan et al., 2004). In India, the genus is represented by more than 200 species that occur mainly in three major centers of diversity, Western Himalayas, North East India, and the Western Ghats (Vivekananthan et al., 1997), of which the state of Kerala harbours 72 species (Nayar et al., 2006), most of which are rare, endangered or threatened.

As part of the survey of rare and threatened plants of Western Ghats, the authors collected Impatiens disotis in Kallar Valley, Idukki District, Kerala, India. Impatiens disotis was described by Joseph Dalton Hooker in 1906, and while he failed to cite specimens, the species was indicated to be restricted to the Travancore and Tinnevely hills. This suggests that he had access to at least two specimens. However, our enquiry of herbaria at Edinburgh, Kew and Manchester proved futile. At this point in time we refrain from designating a neotype pending further investigation. Alfred Meebold, a New Zealand botanical collector, writer and anthroposophist, visited India three times and on his third visit in 1910 he collected I. disotis from Deviculam (Devicolam, Idukki District in what is now the state of Kerala; see http://apps.kew.org; Barcode: K000683314, K). Gamble (1915) accepted Hookers species but it is evident from his description that Gamble never saw the Meebold collection. Bhaskar \& Razi (1978) provided a vague description of flower colour, but as they failed to cite any herbarium specimens to support their findings it is difficult to know how they arrived at their conclusion. In fact, Vivekananthan et al. (1997) went so far as to state that the species had not been collected after 1906, and so seemingly they were unaware of the Meebold collection.
In his monograph on Impatiens of Western Ghats, Bhaskar (2012) treated I. disotis as vulnerable. He pointed out that neither Hooker nor Gamble, or any later worker, provided a detailed description of the species. $\mathrm{He}$ presented a more detailed description based mainly on a B.V. Shetty collection (Shetty 33049, MH!) from the Myhendragiri Hills in the Kanyakumari District region of Tamil Nadu. Here a description, illustration (plate 2) and an array of photographs (plate 3) are provided to facilitate identification of the species.

\section{Impatiens disotis Hooker, 1906}

Hooker, J. D. 1906. An epitome of the British Indian species of Impatiens. Records of the Botical Survey of India, 4: 43, 48, figs. 1 \& 2.

Specimen examined: TBGT 70438; Kallar Valley, Idukki District, Kerala, India; E. S. Santhosh Kumar \& P. E. Roy; 22 Mar 2012.

Herbs 50-100 cm high; stem herbaceous, simple or rarely branched, subterete to shallowly sulcate. Leaves alternate, 7-13 x 4-6 $\mathrm{cm}$; petiole to $3-5 \mathrm{~cm}$ with 1-2 cilia; leaf blade elliptic, elliptic-lanceolate or broadly elliptic with 4-6 pairs of lateral veins, dark green above, pale green beneath, glabrous on both surfaces, attenuate at base, acuminate-caudate acuminate at apex, broadly crenate along margins with minute ciliate. Flowers in axillary racemes, 6-8-flowered, creamy-white with saffron-red patches; peduncle solitary, to $5 \mathrm{~cm}$ long; pedicels 2-3 cm long; bracts subulate, 0.6-0.7 cm long, glabrous; lateral sepals 2, ovate-lanceolate, acuminate at apex, 3-5 nerved, slightly concave, 10-12 x 5-6 mm, pale green; lip cymbiform, slightly compressed laterally, to $14 \mathrm{~mm}$ long, anterior part of mouth with a slightly curved beak to $3 \mathrm{~mm}$ long and a tubular spur to $5 \mathrm{~mm}$ long; standard broadly ovate to suborbicular, keeled along the dorsal side, beaked at apex, 9-10 x 8-9 mm; wing 
petals 3-lobed, 12-16 mm long with basal lobe acuminate at apex and upper lobe ovate-oblong, slightly undulating marginally. Androecium 4.5-5 mm long; filaments to $3.5 \mathrm{~mm}$ long, glabrous; anthers to $1 \mathrm{~mm}$ long. Ovary ellipsoid-ovoid, 1.2-1.6 x 0.5-0.6 cm; style short; stigma obtuse apically. Capsule $2 \mathrm{~cm}$ long, tapering at both ends. Seeds 5-9 per capsule, brownish.

Flowering: December - March

Ecology: Terrestrial, growing in evergreen forests in association with Impatiens goughii (Balsaminaceae), Sarcandra chloranthoides (Chloranthaceae) and Strobilanthes rubicundus (Acanthaceae) at an altitude of $1400 \mathrm{~m}$.

Distribution: India (Kerala and Tamil Nadu), endemic.

Remarks: Impatiens disotis is allied to I. campanulata Wight by its herbaceous habit, alternate leaves, and a spur that is distinctly shorter than the lip. From that species, I. disotis may be distinguished by its oblong sepals with acute apices (not ovate with narrowly acuminate apices) and by its longer spur $(5 \mathrm{~cm}$ vs $2-2.5 \mathrm{~mm}$ long).

\section{Acknowledgements}

The authors are grateful to the Director (JNTBGRI), P. G. Latha, for use of the facilities and for her encouragement. They are also thankful to J. F. Veldkamp (National Herbarium, Netherlands), The Keeper and The Indian Liaison Officer of the Royal Botanic Gardens, Kew for their consultation, and to the Kerala Forest Department for permission to conduct our research. Finally Steven Janssens (KU Leuven - Belgium) is acknowledged for valuable comments and reviewing.

\section{Literature Cited}

Bhaskar, V. and B. A. Razi, 1978. Studies on south Indian Impatiens L. II. General. Indian Journal of Forestry, 1: 191-198.

Bhaskar, V., 2012. Taxonomic monograph on Impatiens L. (Balsaminaceae) of Western Ghats, South India. The key genus of endemism. Centre for Plant Taxonomic Studies, Bangalore: 239.
Gamble, J. S., 1915. Flora of the Presidency of Madras. Volume 1, part 1. Adlard \& Son, London: 144.

Hooker, J. D. 1906. An epitome of the British Indian species of Impatiens. Records of the Botical Survey of India, 4: 37-58.

Janssens, S., E. Knox, S. Huysmans, E. Smets and V. Merckx, 2009. Rapid radiation of Impatiens (Balsaminaceae) during Pliocene and Pleistocene: Result of global climate change. Molecular Phylogenetics and Evolution, 52: 806-824.

Nayar, T. S., B. Rasiya, N. Mohanan, and G. Raj Kumar, 2006. Flowering plants of Kerala $-A$ handbook. Tropical Botanic Garden and Research Institute, Thiruvananthapuram: 133.

Vivekananthan, K., N. C. Nair, M. S. Swaminathan and L. K. Ghara, 1997. Balsaminaceae. Flora of India, 4: 93-102.

Yuan, Y. -M., Y. Song, K. Geuten, E. Rahelivololona, S. Wohlhauser, E. Fischer, E. Smets and P. Küpfer, 2004. Phylogeny and biogeography of Balsaminaceae inferred from ITS sequences. Taxon, 53: 391-403.

Submitted: 5 October 2012, Accepted: 16 October 2012 Sectional Editor: James L. Reveal E. S. Santhosh Kumar
A. G. Pandurangan ${ }^{1}$ and P. E. Roy

${ }^{1}$ Jawaharlal Nehru Tropical Botanic Garden \& Research Institute, Palode, Kerala 695562, India E mail: santhoshkumares@gmail.com² 


\section{PLATE 02}

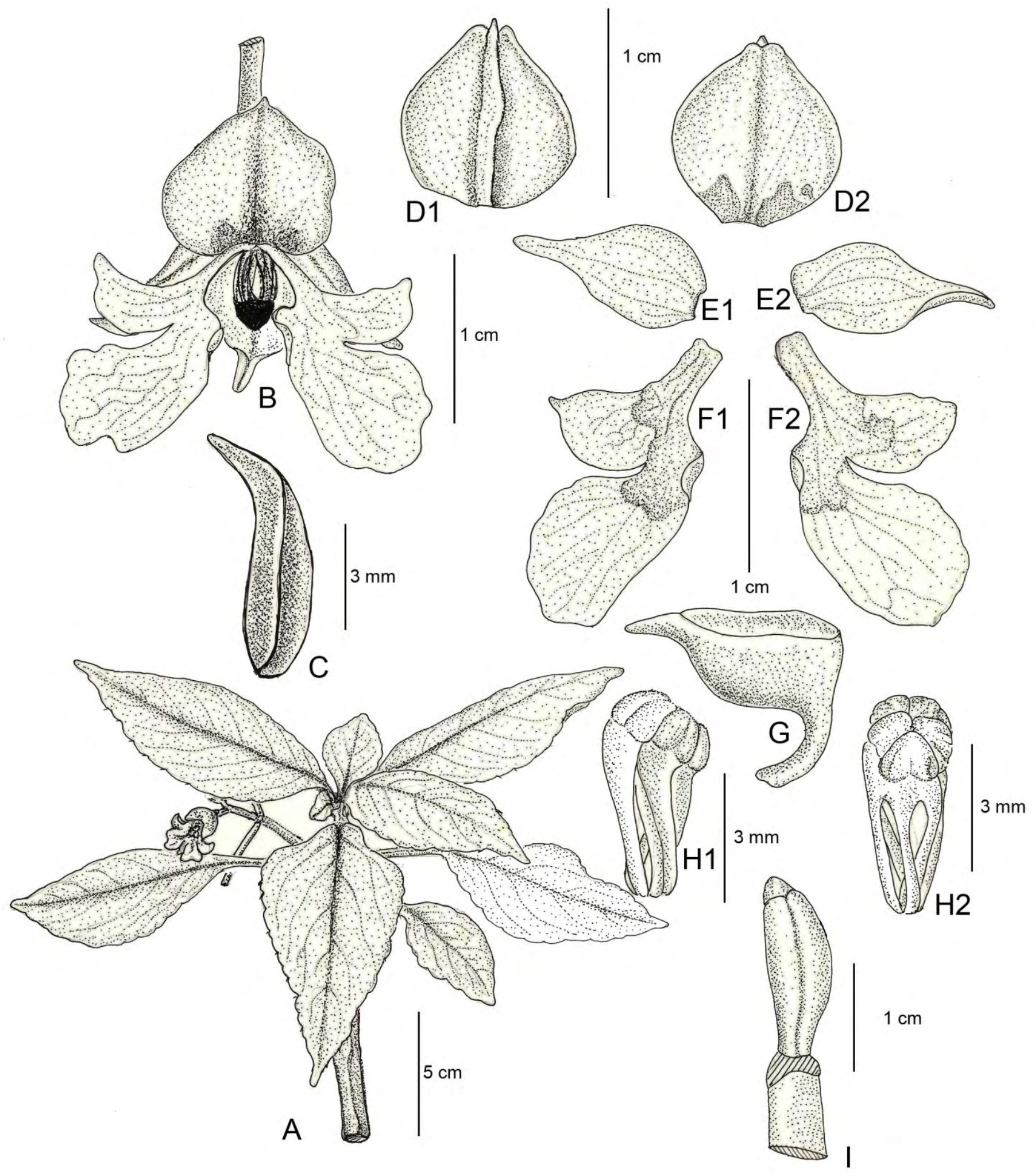

Figure 1: Impatiens disotis, A, Twig; B, Flower; C, Bract; D1, Standard petal (dorsal view); D2, Standard petals (ventral view); E1 \& E2, Lateral sepals; F1 \& F2, Wing petals; G, Lip; H1 \& H2, Stamens; I. Capsule (immature). 


\section{PLATE 03}
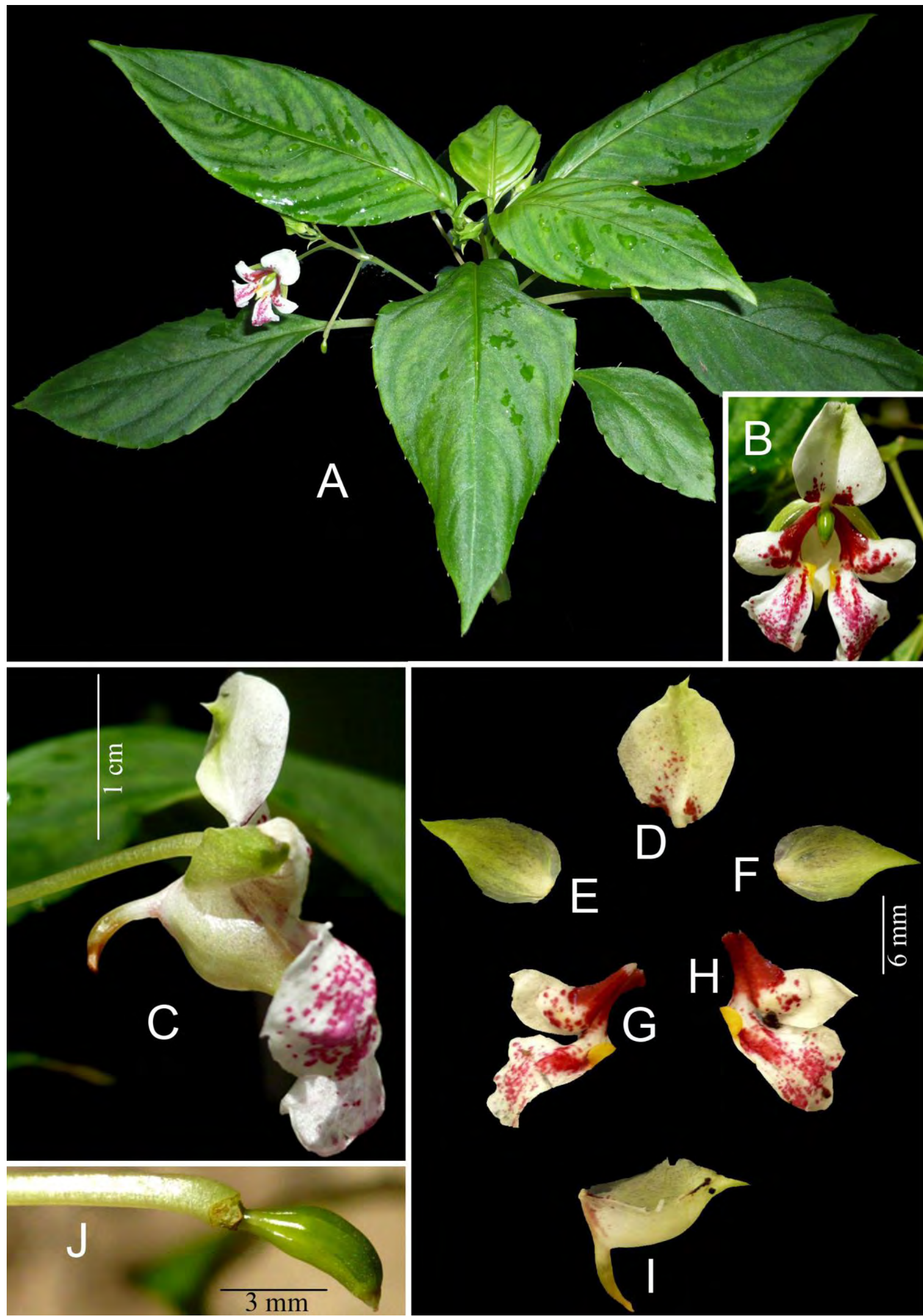

Figure 2: Impatiens disotis, A, Twig; B, Flower (front view); C, Flower (lateral view); D, Dorsal petal; E \& F, Lateral sepals; G \& H, Wing petals; I, Lip; J, Capsule (immature). 